\title{
超伝導体内部界面の原子構造
}

\author{
石田洋一・简僠裕* \\ 東京大学生産技術研究所 T106 東京都港区六本木 7-22-1 \\ * 東京大学工学部精密機械工学科 $\mathbf{T} 113$ 東京都文京区本郷 7-3-1 \\ (1989 年 8 月 5 日 受理)
}

\section{Atomic Structure of Internal Interfaces in Superconducting Oxides}

\author{
Yoichi ISHIDA and Yutaka TAKAHASHI* \\ Institute of Industrial Science, The University of Tokyo \\ 7-22-1 Roppongi, Minato-ku, Tokyo, 106 \\ * Department of Precision Machinery Engineering, Faculty of Engineering, The University of Tokyo \\ 7-3-1 Hongo, Bunkyo-ku, Tokyo,113
}

(Received August 5, 1989)

高温超伝導酸化物 $\mathrm{YBa}_{2} \mathrm{Cu}_{3} \mathrm{O}_{7-x}<\mathrm{Bi}_{2} \mathrm{Sr}_{2} \mathrm{CaCu}_{2} \mathrm{O}_{x}$ の結昆粒界の高分解能電子湿微鏡によ万組織学的解 析と双結晶を用いた直流伝導測定の結果を比較し, 内部界面の原子構造之電気伝尊特性の関連について考察 した。

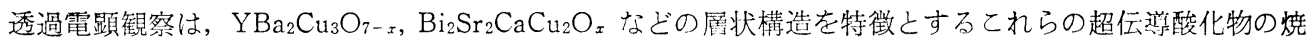
結体が一方の結晶の底面に平行な，いわゆる底面粒界を多く含むととを示し，超伝導性は特にとの結晶粒界 で弱いととが予想された。

しかしながら [001] ねじり粒界を持つ $\mathrm{Bi}_{2} \mathrm{Sr}_{2} \mathrm{CaCu}_{2} \mathrm{O}_{x}$ 双結鼠に扔ける超伝尊性の測定は, 単結鼠と比較し て, その臨界温度㧍よび臨界霓流とも大差ないととを示した。この結果は Dimos らが行った $\mathrm{YBa}_{2} \mathrm{Cu}_{3} \mathrm{O}_{7-x}$ の [001]対称傾角双結晶の結果と矛盾する。

これらの差異について議諭を行い,

1) $\mathrm{YBa}_{2} \mathrm{Cu}_{3} \mathrm{O}_{7-x}$ と $\mathrm{Bi}_{2} \mathrm{Sr}_{2} \mathrm{CaCu}_{2} \mathrm{O}_{x}$ の結䀯構造の差

2) 作製した $\mathrm{Bi}_{2} \mathrm{Sr}_{2} \mathrm{CaCu}_{2} \mathrm{O}_{x}$ 双結昆の粒界微細構造の影響

の可能性を指摘した。そして，今後ての種の双結昆実験を精力的に行い，単一の粒界の電気伝導特性と微細 構造を対比することが酸化物超伝導体の粒界研究に必要であることを強調した。

\section{1.はじめに}

最近の酸化物超伝導体に㧈いて内部界面である結晶粒 界が注目されている理由は 2 つる。1つは負の効果で あり, 結晶粒界が超伝導電流の流れの障害となっている という立場である1)。燒結体の臨界電流値 $\left(J_{\mathrm{c}}\right)$ が（巣結 晶）薄膜と比較して桁違いに小さいのは粒界の弱結合に よるむのであり，1つの結晶精内では大きな $J_{\mathrm{c}}$ 值が得 られているにもかかわらず巨視的には非常に小さな電流 しか取り出せないというあのである。むう1つは正の効 果である。これらの酸化物超伝導体は旌 2 種であり, 下 部臨界磁場が非常に小さいため, 高い $J_{\mathrm{c}}$ 值を得るため には混合領域での磁束線のピン止めが必琹である。合金
系2)および A 15 型系3)で成功したように結晶粒界にと の役割を担わせ，結晶粒径を微細化することにより高密 度のピン止め点を導入し， $J_{\mathrm{c}}$ 值を改善する可能性も否 定できないからである。

この他にあセラミックス其通の課題として破塤の起源 が結哭粒界にあるといったととや，Y系超伝導体におけ 万水分の劣化においては粒界が水の高速拡散路として作 用していることや，高温での熱サイクルに対して变態歪 による精界割れをおこしやすいことなど，奏用化に対し て絬昆粮界の諸問題は手付が゙のまま山積している。

Y系超伝澊体か溌見されたとき，乙の超伝導性化何ら 加の界面珪像が関与しているという Chu らの提唱4に 筷者らは強く刺激され超伝導の研究を始めたが, その後 
の他の研究者による注意深い追試からこの考えはほとん ど否定されてしまった。そのかわりに実際上，ての物質 を材料として使用する立場から, 悪者としての結晶粒界 の役割りが重要な検討課題に挙がってきた。本稿では高 分解能電子顕微鏡 (以下, 電顕と略す) を用いて微細構 造を見る立場から, $\mathrm{YBa}_{2} \mathrm{Cu}_{3} \mathrm{O}_{7-x} \quad\left(T_{\mathrm{c}}=90 \mathrm{~K}\right)$ および $\mathrm{Bi}_{2} \mathrm{Sr}_{2} \mathrm{CaCu}_{2} \mathrm{O}_{x}\left(T_{\mathrm{c}}=80 \mathrm{~K}\right)$ の結晶内部界面と超伝導性 の関連についての最近の研究成果について報告する。

\section{2. $\mathrm{YBa}_{2} \mathrm{Cu}_{3} \mathrm{O}_{7-x}$ における [001] 対称傾角粒 界双結晶の臨界電流值}

$\mathrm{YBa}_{2} \mathrm{Cu}_{3} \mathrm{O}_{7-x}$ の発見当初, 焼結体試料においては直 接的に電流を流して電圧を測定する方法（直接法）で得 られた $J_{\mathrm{c}}$ 值は数 $10 \mathrm{~A} / \mathrm{cm}^{2}$ と非常に小さな値しか得ら れず，実用的には全く使い物にならないてとが惩念され た。とてろが帯磁率測定から Bean の式占を使って求め た $J_{\mathrm{c}}$ 值は非常に大きな值を示し ${ }^{1)}$, また薄膜ではすぐ さま $10^{3} \mathrm{~A} / \mathrm{cm}^{2}$ が達成されたため, この差がどてから来 るのかということが注目の的となった。そして結晶粒界 があやしいというととで意見が収束していった。

これを決定付けたのが IBM グループの Dimos ら が行った双結晶薄膜の $J_{\mathrm{c}}$ 測定の実験である ${ }^{6)}$ 。乙れは $\mathrm{YBa}_{2} \mathrm{Cu}_{3} \mathrm{O}_{7-x}$ を $\mathrm{SrTiO}_{3}$ 双結晶上にエピタキシャル成 長させるととにより [001]対称傾角粒界を作製し，粒界 を横切る臨界電流值 $J_{\mathrm{c}} \mathrm{g}^{\mathrm{b} b}$ と傾角 $\theta$ との関係を調べた（図 1 , 縦軸はバルク内の臨界電流值 $J_{\mathrm{c}}^{\mathrm{B}}$ で規格化した)。 双結晶を用いて個々の粒界の $J_{\mathrm{c}}$ 特性を系統的に調へたた という粒界研究の伝統的手法に基づいた成果というだけ でなく，Jab が傾角 $15^{\circ}$ 以下（いわゆる小角領域）で 急激に低下し，大角領域で飽和することが注目された。

一般に小角領域での傾角粒界は格子転位の列として記 述できるため(図 2), $\theta$ の増加に伴う $J_{\mathrm{c}^{\mathrm{g}}}$ 減少から 転位芯近傍 $1 \mathrm{~nm}$ 程度の領域で超伝導性が破れているて

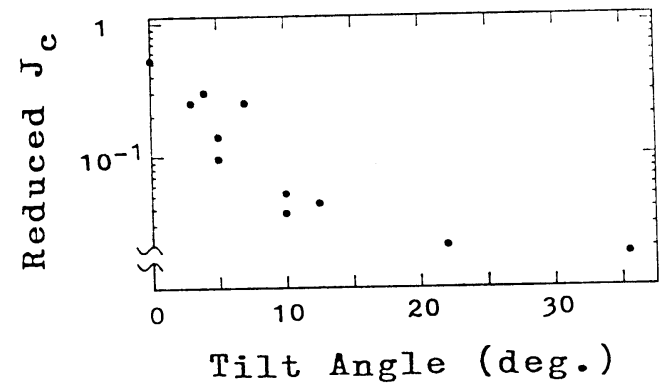

图 $1 \mathrm{YBa}_{2} \mathrm{Cu}_{3} \mathrm{O}_{7-x}$ の対称傾角粒界双結晶にお ける粒界を横切る臨界電流密度の傾角依存性 (Dimos et al. $\left.{ }^{6}\right)$ 。(縱軸はバルク内の臨界電流 密度で規格化した。)

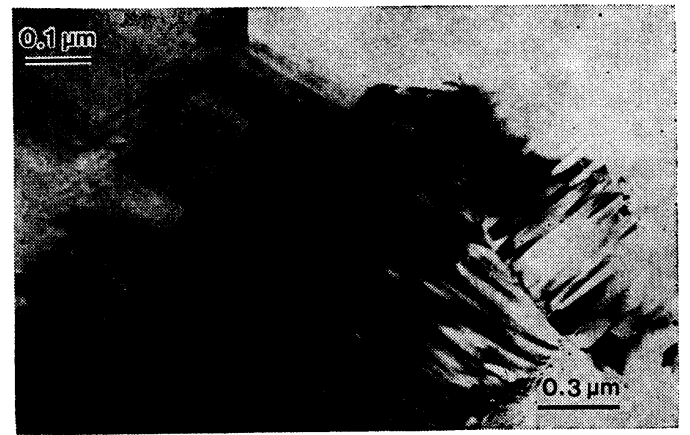

図 $2 \mathrm{YBa}_{2} \mathrm{Cu}_{3} \mathrm{O}_{7-x}$ 中の小角粒界の明視野像。(四 中の線状の並びは転位列である。)

とが見積むられる7。 そして大角領域で飽和するととは 粒界がコヒーレンス長と同じ程度の幅を持った非超伝導 領域（つまり弱結合部）であるととを意味する。対称傾 角粒界は最も超伝導電流が流れやすい c 面が互いの結晶 粒で平行であるにあかかわらずバルク值の $1 / 50$ 程度ま で低下するということは，一般粒界ではさらに小さい值 で超伝導性が破れるというととを示唆する。

\section{3. $\mathrm{YBa}_{2} \mathrm{Cu}_{3} \mathrm{O}_{7-x}$ および $\mathrm{Bi}_{2} \mathrm{Sr}_{2} \mathrm{CaCu}_{2} \mathrm{O}_{x}$ 中の 底面粒界の構造}

結晶粒界の中で一方の結晶の $\mathrm{c}$ 面（底面）に平行な粒 界（以下 “底面粒界” と呼ぶ）は， c 軸方向のコヒーレ ンス長が短いため8,9 超伝導電流の流れる経路としては 大きな障害になることが予想される。一方, 困ったてと にこの物質の層状性を反映して, $\mathrm{YBa}_{2} \mathrm{Cu}_{3} \mathrm{O}_{7-x}, \mathrm{Bi}_{2} \mathrm{Sr}_{2}$ $\mathrm{CaCu}_{2} \mathrm{O}_{x}$ のいずれにおいてあ焼結体試料ではこの底面 粒界の頻度が高い。

図 3 は $\mathrm{YBa}_{2} \mathrm{Cu}_{3} \mathrm{O}_{7-x}$ 中の底面粒界の観察例である。 焼結法においては仮焼後に焼結に先立って破碎を行うた め，底面においてへき開が生じ等方的な微細粉にならな い。これを焼結すれば粒界面が底面に平行になりやすい ことは容易に考えられる。さらに焼結中の粒成長を起と す際に底面に平行になるように優先成長することはこの 傾向を助長する（このととは焼結温度を $1000^{\circ} \mathrm{C}$ 程度に 設定し, $0.1 \mathrm{~mm}$ 程度まで粗大化させた試料を光学顕微 鏡で観察すれば平板状の結晶粒が多数見られることから あ分加る。

$\mathrm{Bi}_{2} \mathrm{Sr}_{2} \mathrm{CaCu}_{2} \mathrm{O}_{x}$ においてあ事情は同様であるが, ペロ ブスカイトユニットの他に $\mathrm{Bi}_{2} \mathrm{O}_{2}$ 層を含むととによる 特異性を生じる。図 4 はこれを示した写真で, $\mathrm{Bi}_{2} \mathrm{O}_{2}$ 層 が粒界面となっている。この写真ではいずれの黒点がペ ロブスカイトユニットまたは $\mathrm{Bi}_{2} \mathrm{O}_{2}$ 層の原子であるか は明瞭でないが, はっきりと区別できる部分から点を 追っていくと粒界部は $\mathrm{Bi}_{2} \mathrm{O}_{2}$ 首であることが, $\mathrm{Bi}_{2} \mathrm{Sr}_{2}$ - 


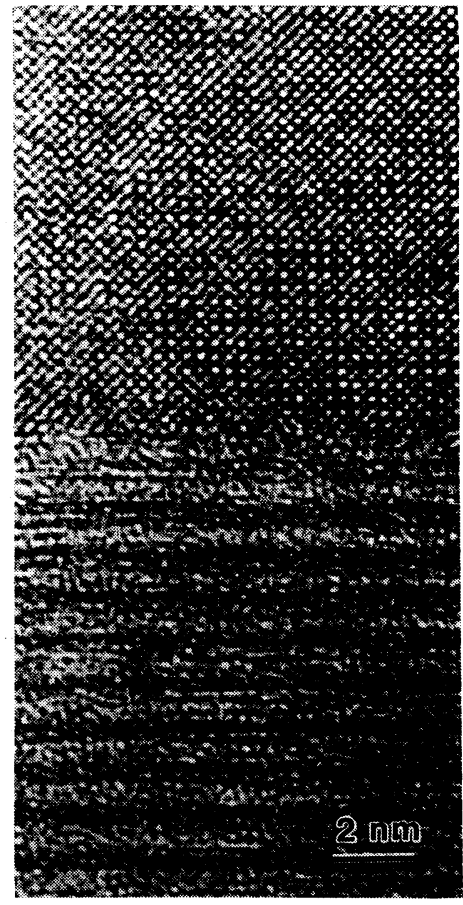

図 $3 、 \mathrm{YBa}_{2} \mathrm{Cu}_{3} \mathrm{O}_{7-x}$ 焼結体中に観察された底面粒 界の高分解能像。（粒界面は下方の結晶粒の c 面 に平行である。)

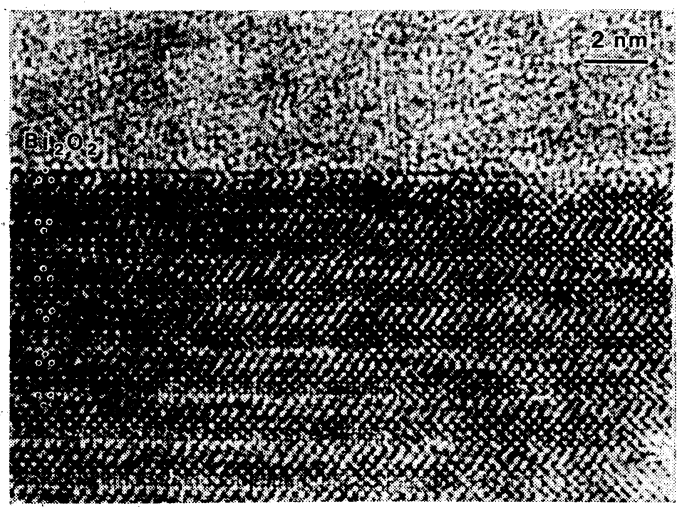

図 $4 \mathrm{Bi}_{2} \mathrm{Sr}_{2} \mathrm{CaCu}_{2} \mathrm{O}_{x}$ 焼結体中に観察された底面 粒界の高分解能像。（図中左端の○は $\mathrm{Bi}$ 層を表 す。)

$\mathrm{CaCu}_{2} \mathrm{O}_{x}$ に特徵的な 2 本線の存在から経験的に直ちに 分かる。このような構造をとる理由としては 2 枚の $\mathrm{Bi}$ 層の凝縮エネルギーが低いととがこれを界面とする粒界 のエネルギーを低下させているためと推定される。

\section{4. $\mathrm{Bi}_{2} \mathrm{Sr}_{2} \mathrm{CaCu}_{2} \mathrm{O}_{x}$ の [001] ねじり粒界の生 成頻度}

底面粒界の特殊な例として両方の結晶の底面が粒界面 となる場合があり，粒界理論ではこれを [001]ねじり粒

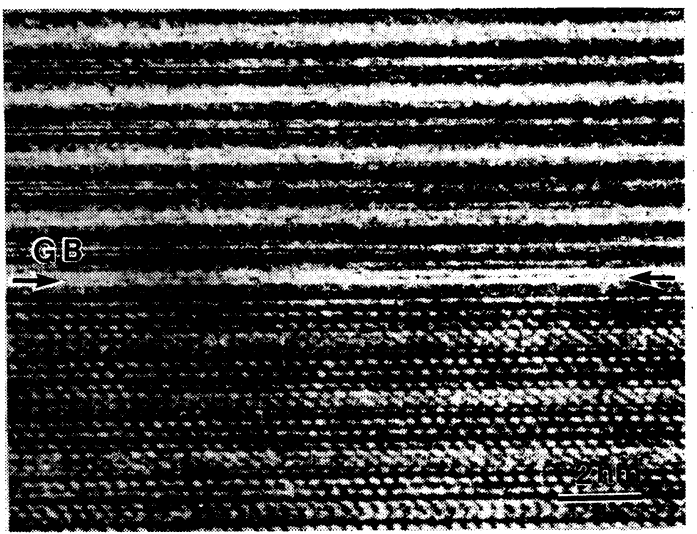

图 $5 \mathrm{Bi}_{2} \mathrm{Sr}_{2} \mathrm{CaCu}_{2} \mathrm{O}_{x}$ 中の [001] 㸚じり䊀界の高 分解能像。

界と呼ぶ。 $\mathrm{Bi}$ 系超伝導体ではこの粒界が非常に生成し やすい。溶融法で作製した試料では底面に平行な薄板状 の結晶が積み重なった組織が良く見られ，自然に生成す ることはこの粓界の安定性を示唆する。これは固相反応 法で試料作製をした場合でも同様であり， $\mathrm{Bi}_{2} \mathrm{Sr}_{2} \mathrm{CaCu}_{2}$ $\mathrm{O}_{x}$ の観察例を図 5 亿示す ${ }^{10)}$ 。互いの結晶粒の $\mathrm{c}$ 軸は平 行であり, 電子線回折図形の解析から小角粒界に属すこ とが分かっている。乙の場合も図 4 と同様に $\mathrm{Bi}_{2} \mathrm{O}_{2}$ 層が 粒界面となっているが，[001] ねじり粒界は点対称な構 造であるため幾何学的には 2 枚の $\mathrm{Bi}$ 面の中間で粒界面 を定義するのが妥当である。

$\mathrm{Bi}$ 系超伝導物質は $a=b=0.54 \mathrm{~nm}$ の擬正方晶である ため，底面の構造は正方形である。このためこの 2 枚の 正方形を貼り合わせた $[001]$ ねじり粒界は特定のねじり 角 $\phi$ において短周期の 2 次元規則構造を作る。最も自

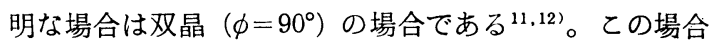
は完全に格子点は一致するが, $\mathrm{b}$ 軸方向に変調構造を有 することにより結晶学的には $\mathrm{a}$ 軸と $\mathrm{b}$ 軸が等価でないた め界面の一種類と見なされなければならない。他の典型 例としては, $[001]$ 軸まわりの $\phi=36.9^{\circ}$ 回転 $\left(\sum=5\right.$ 方 位関係）が明快である。簡単な作図から分かるように， 母格子の $\sqrt{5}$ 倍の大きさの正方形周期構造を成す。この 面積を $\Sigma$ 值と定義し, この值が小さい方位がエネルギ 一的に安定であると提唱するのが幾何学的考察に立脚し た “対応格子 (コインシデンス) 理論” の教えるところ である。

粒界のエネルギー安定性はその分布に顕著に表れる。 たとえば前項で示した底面粒界が頻々と観察されること はその構造の安定性の現われである。 $\mathrm{YBa}_{2} \mathrm{Cu}_{3} \mathrm{O}_{7-x}$ 系 においてこれを定量的に取り扱った研究として Smith らの結果を図 6 に示す ${ }^{13)}$ 。溶融法で作製した $\mathrm{YBa}_{2} \mathrm{Cu}_{3}$ $\mathrm{O}_{7-x}$ においては $\mathrm{a}, \mathrm{b}$, c 面をファセット面としたサ 


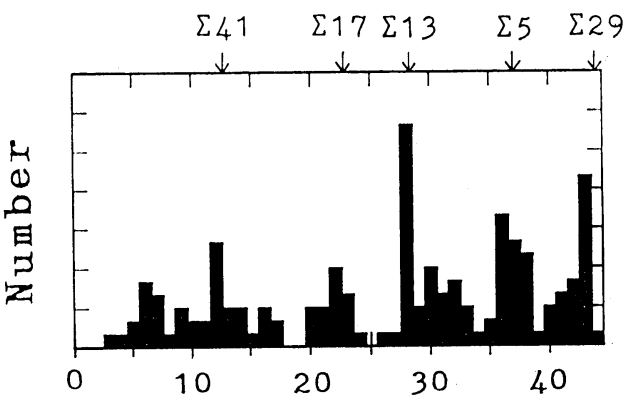

Twist Angle (deg.)

図 6 溶融法で作製した $\mathrm{YBa}_{2} \mathrm{Cu}_{3} \mathrm{O}_{7-x}$ 中の [001] ねじり粒界のねじり角の分布 [Smith el al. ${ }^{13)}$ 。

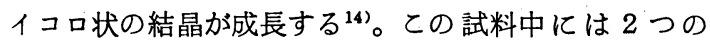
結晶が積み重なった [001] ねじり境界を持つものが存在 し， 走査電顕観察からそれぞれのサイコロの㲽のなす角 の分布を調べた。この図においては随所にピークが見ら れ, 分布に優先方位が存在する。 $\mathrm{YBa}_{2} \mathrm{Cu}_{3} \mathrm{O}_{7-x}$ は $\mathrm{a} \fallingdotseq \mathrm{b}$ $\fallingdotseq \mathrm{c} / 3$ の斜方晶であるため近似的に立方晶系の対応粒界 理論を適用することが可能であり，それぞれのピークは $\Sigma=41,17,13,5,29$ に対応すると解釈される。

対応方位関係の出現確率が高い傾向は $\mathrm{Bi}$ 系超伝導体 にあ見られる。図 7 は [001]方向（つまり粒界面が紙面 に平行になる方向）からねじり粒界を観察したあのであ る。明視野像においてクモのように見える部分は $\boldsymbol{g}=$ 200,220,020, $2 \overline{2} 0$ に対応する等傾角干渉縞であり, 単結 晶を観察した場合の足は 8 本である。ところがこの場合 は 2 つ結晶が重なっているため 16 本となる。電子線 回折図形においては主反射の他に 2 重回折による斑点も 現われており，結晶方位は [001]軸まわりの $\phi=26^{\circ}$ 回 転,つまり $\Sigma=13$ ねじり粒界である。

同様の電顕観察を繰り返すと，最むよく観察されるの は小角粒界 $\left(\phi<15^{\circ}\right)$ であった。乙れは他の材料であ同 じように小角粒界の頻度は最む高いのが普通である。次 によく観察されるのが双晶 $\left(\phi=90^{\circ}\right)$ であり，完全なエ ピタキシー関係を満足するためその安定性は自明であろ う。その他の場合においてはランダム粒界以外に $\Sigma=$ $13,17,25$ と同定できる場合も観察された ${ }^{15)}$ 。通常, 透 過電顕による定量化は困難であり, 偶然にその方位に合

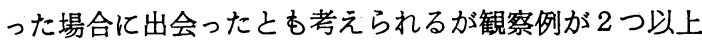
得られた場合ああり， $\mathrm{Bi}$ 系超伝導体の [001] ねじり粒 界では対応方位が優先的に出現する傾向があると結論さ れる。つまり $\mathrm{YBa}_{2} \mathrm{Cu}_{3} \mathrm{O}_{7-x}, \mathrm{Bi}_{2} \mathrm{Sr}_{2} \mathrm{CaCu}_{2} \mathrm{O}_{x}$ などの層状 ペロブスカイト酸化物の [001] ねじり粒界の安定性は, 対応粒界理論により説明されると考えて良いであろう。

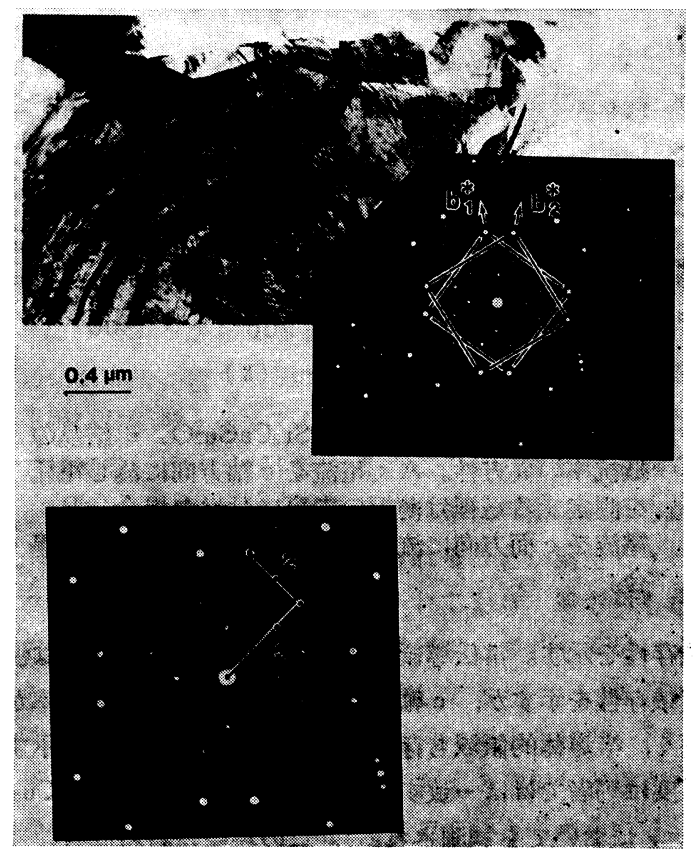

図 $7 . \mathrm{Bi}_{2} \mathrm{Sr}_{2} \mathrm{CaCu}_{2} \mathrm{O}_{x}$ 中の $\Sigma 13$ ねじり粒界の明視 野像之電子線回折図形。(明視野像において粒界 面は紙面に平行であり, クモ形膜様は等傾角干涉 縞である。電子線回折図形中の $\mathrm{b}_{\mathrm{i}}{ }^{*}$ はそれぞれの 結晶の $\mathrm{b}$ 軸方向を表す。 2 重回折した斑点の解析 から方位は $\Sigma=3^{2}+2^{2}=13$ である。)

\section{5. $\mathrm{Bi}_{2} \mathrm{Sr}_{2} \mathrm{CaCu}_{2} \mathrm{O}_{x}$ の [001] ねじり双結晶の 電気伝導特性}

筆者らこの 3 年間, 透過電顕観察を主力に酸化物超伝 導体の研究を進めてきた。一方最近, 前章で示したよう に Bi 系超伝導体では [001]ねじり粒界が生成しやすい ことに着目して，この双結晶を作製する作業をあ精力的 に進めている ${ }^{16)}$ 。自然界が作るむのは人工的にあ作りや すいであろうと予想している。狙いは Dimos ら ${ }^{6}$ が行 ったような粒界弱結合の直接的な検証であり, “論より 証拠”をというわけである。目下, 対応方位において超 伝導特性に特異性が観測されるか否かが主な興味である が，将来的には単一の粒界における粒界ジョセフソン接 合の特性についても検討したいと計画している。

双結晶の作製は焼結法により行った。 $\mathrm{Bi}-\mathrm{Sr}-\mathrm{Ca}-\mathrm{Cu}-\mathrm{O}$ 融液を徐冷し板状の結晶を液相成長させ, 機械的に取り 出した数 $\mathrm{mm} \times$ 数 $\mathrm{mm} \times \sim 0.1 \mathrm{~mm}$ の単結晶をへき開に より清浄面を得る。乙れを 2 枚重的合わせてアルミナ板 の上で無荷重下で焼結を行う。接合を成功させるために は試料が溶解する直下に保持させることが鍵である。

図 8 にこの単結晶試料の 4 端子法による抵抗率の温度 


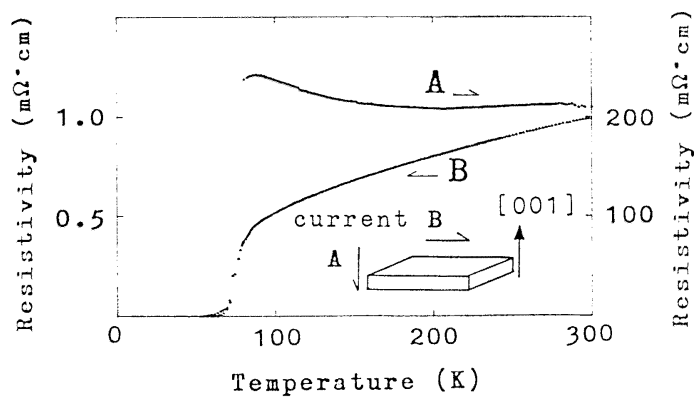

図 8 溶融法で作製した $\mathrm{Bi}_{2} \mathrm{Sr}_{2} \mathrm{CaCu}_{2} \mathrm{O}_{x}$ 単結晶の 抵抗率の異方性。A：電流を $\mathrm{c}$ 軸方向に流し電压 を測定する電極は薄板の表裏に付けた場合，B： 電流を $\mathrm{c}$ 面方向に流し，電極を同じ側に付けた場 合。

依存性を示す。常伝導領域において c 面内は金属的な温 度依存性を示すが, $\mathrm{c}$ 軸方向は前者と比較して抵抗率が 高く, 半導体的領域む存在する。ところが零抵抗を示す 温度は両者でほぼ一致する（同様の異方性は $\mathrm{YBa}_{2} \mathrm{Cu}_{3}$ $\mathrm{O}_{7-x}$ においても観測される)。乙の現象は材料固有の性 質とあ考えられるが，本試料の均質性に問題があること も考えられる ${ }^{17,18)}$ 。つまりX線的には $\mathrm{c}=3.1 \mathrm{~nm}$ の単 相であることを確認しているが，サイト置換による濃度 変調が生じている可能性があるからである。

図 9 には双結晶試料（図中の試料B）の抵抗率の温度 依存性を示した。約 $75 \mathrm{~K}$ で超伝導遷移を示し測定精度 内 $( \pm 1 \mu \mathrm{V})$ において零抵抗にまで落ちる。このことは 粒界部に抵抗を発生するような異相が生成していないて とを意味する。

この結果との比較のために単結晶（試料C，図8の試 料とは異なる）および固相反応法で作製した $80 \mathrm{~K}$ 相 (試料 $\mathrm{A}$ ，多結晶）の $\rho-T$ 曲線もあわせて載せた。話題 が前後するが $\mathrm{Bi}$ 系超伝導においては $\mathrm{Pb}$ を添加 ${ }^{19)}$ しな い場合，一般的に融液から作製した試料 ${ }^{20)}$ の方が固相反

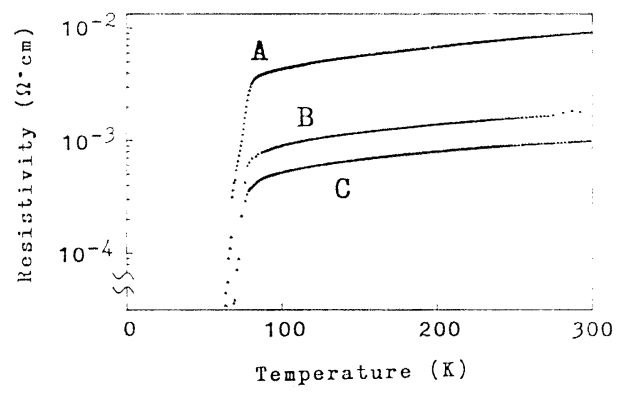

図 $9 \mathrm{~A}$ : 固相反応法で作製した試料，B：双結晶 および C：単結晶の抵抗率の温度依存性。(縦軸 が対数でプロットしてあるととに注意。
応法で作製した試料よりも $\rho-T$ 曲線的には良質の試料 が得られる。試料 $\mathrm{A} と \mathrm{C} の$ 比較むこの場合に相当すると 考えられるが，この原因については明快な説明がなされ ていないようである。

一方，双結晶（武料B）は塑結昆（武料C）とほとん ど差が認められない。つまり，常伝導領域においては金 属的温度依存性を示し，抵抗率もほとんど差がなく（双 結晶においては形状因子からの抵抗率への算出が難しく 数倍の䛊差を含む)，零抵抗を示す溜度もほぼ一致する。 この結果は [001]秝じり粒界が超伝導電流の流れに刘し て大きな障害になっていないとと赤唆する。確かに電 流密度を上げた $\rho-T$ 測定では双結鼠において抵抗率低 下の裾（tail）が大きくなり粓界の弱結合を暗示するが, これは粒界にポアが多量に存在するため接合湎積が減少 していることが原因とも考えられる。また㨁接法による 臨界電流測定では（電流端子の電極部のジュール発熱の 影響によりきれいなデータは測定できていないが）単結 晶と双結晶の差は数倍程度であり少なくとも桁が違うと いうことはない。

むしての結果が示すように $\mathrm{Bi}_{2} \mathrm{Sr}_{2} \mathrm{CaCu}_{2} \mathrm{O}_{x}$ において [001] ねじり粒界が障害となっていないとすると，今ま での考えを大幅に修正せざるを得ない。この問題に関し ては以下の 2 つの点を指摘しておく。まず第 1 点は, $\mathrm{YBa}_{2} \mathrm{Cu}_{3} \mathrm{O}_{7-x}$ も $\mathrm{Bi}_{2} \mathrm{Sr}_{2} \mathrm{CaCu}_{2} \mathrm{O}_{x}$ 屯屏状構造であり超伝 導特性に関して $\mathrm{c}$ 面方向と $\mathrm{c}$ 軸方向は大きな異方性を持 つが，構造的には前者がペロブスカイトユニットのみで 構成されるのに対して後者は $\mathrm{Bi}_{2} \mathrm{O}_{2}$ 曆が付け加わって いることである。つまり, $\mathrm{Bi}_{2} \mathrm{O}_{2}$ 層は 2 枚の $\mathrm{Bi}$ 面が約 $0.32 \mathrm{~nm}$ あ隔てられた構造であり弱いファンデアワール ス力で結合されていると考えられている。このため $\mathrm{Bi}_{2} \mathrm{O}_{2}$ 層で構成される [001] 㸚じり粒焽は歪が小さい。 歪が小さいからこそ粒界エネルギーが低く，自然に発生 しやすいのである。このため粒器近傍での原子配列の乱 れが少なく超伝導性が弱められていないと考えられる。 第 2 点は得られた双結晶試料が完全なねじり粒界になっ ているか否かという点である。 $\mathrm{Bi}_{2} \mathrm{Sr}_{2} \mathrm{CaCu}_{2} \mathrm{O}_{x}$ を $\mathrm{c}$ 面へ き開させると雲母のように段差が生じて割れる（これは 破砕法で作製した電顕試料を観察してみると良く分か る)。とのためマクロ的に平坦な単結晶表面においてもミ クロ的には凹凸があり，乙れを接合した試料は礼じり粒 界とステップ状の傾角粒界により構成されることが考え られ，超伝導電流はこの部分を流れる。夹際に焼結体試 料で観察された図 10 の例ではこのようなととは起こり うるととを示す ${ }^{10)}$ 。 $\mathrm{c}$ 軸長の半分のステップが見られ， これは粒界面が $\mathrm{Bi}_{2} \mathrm{O}_{2}$ 層で構成されるためである(つま りステップ高さは c/2 の整数倍になる)。 

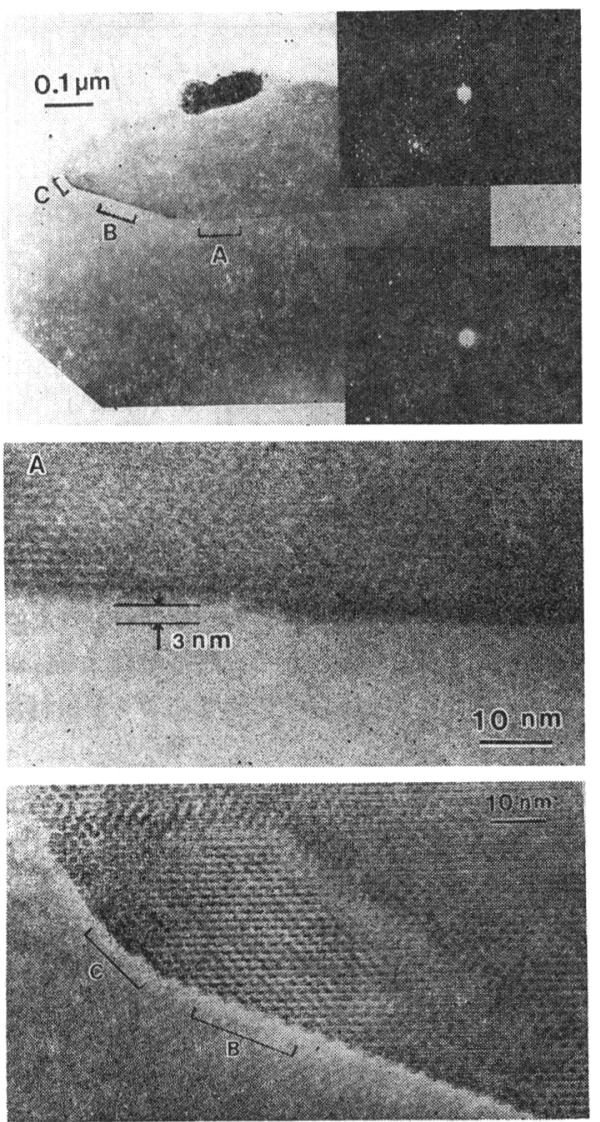

図 10 烧結法で作製した $\mathrm{Bi}_{2} \mathrm{Sr}_{2} \mathrm{CaCu}_{2} \mathrm{O}_{x}$ 中の底面 精界におけるステップ。部分 $\mathrm{A}$ ：ステップ高さは $\mathrm{c} / 2$ 単位亡なる, 部分 $\mathrm{B}: \mathrm{Bi}$-concenrated band を包絡するような周期構造が見られる, 部分 C : 特別な傾向は見られない。

\section{ここで述べた 2 点の指摘も “論より証拠”である。} Dimos ら ${ }^{6}$ 拈よび筆者らが行った方法により， $\mathrm{YBa}_{2} \mathrm{Cu}_{3}$ $\mathrm{O}_{7-x}$ および $\mathrm{Bi}_{2} \mathrm{Sr}_{2} \mathrm{CaCu}_{2} \mathrm{O}_{x}$ の対称傾角およびねじり双 結晶を作製して，4者の比較を行うことが最も雄弁に粒 界の電気伝導特性を物語る。そして単一の粒界で構成さ れる試料の電気的特性の測定之高分解能透過電顕観察を 組み合わせることが超伝導体中の粒界研究に新しい展開 をあたらすと期待される。

\section{6.おわりに}

透過型電顕による高分解能観察は, 酸化物超伝導体の 微細構造を解析するために無類の威力を発揮した。とこ ろが見ている視野の超伝導特性を測定しながら観察を行 うというわけにはいかないため, ミクロな観察結果とマ クロな電気的特性之の相関にはある程度の隔たりがあっ た。
最近，臨界電流密度との関連で結晶粒界は非常に注目 されており，このミクロとマクロの溝を埋める工夫をし なければならない。1つの提案としてはすでに述べたよ うに双結晶を用いた実験が有力である。

また，電顕の立場からは低温観察が興味深い。観察中 に試料は対物レンズからの数テスラの磁場にさらされる ため，虫磁場下での超伝導挙動をシミュレートしている ことに相当するからである。すでに電顕においてはロー レンツ観察法上いう手法が確立されているように ${ }^{211}$ ，磁 性を带びた領域とそうでない領域はコントラストの差と して観察を行うことができる。このため完全反磁性で ある超伝導領域上磁束が侵人した非超伝導領域の分布か ら、ボルテックスの様子が観察されることが期待できる このような試みはすでに進められており，筆者らあか つて行ったが22)，現在までその成果は必ずしも満足いく 屯のではない。その問題点は判明しており，（1)低温ス テージの改良, (2) 新しい薄膜試料作製法の開発, (3) イメージングプレートなどの記録媒体の選択など現在の 電顕技術を総動員すれば克服可能であると考えられる。 磁束が粓界に沿って移動する様子(フラックスフロー) が観察されることは筆者ら電顕屋が当初から見つづけて いる夢である。

\section{文 献}

1) H. Kumakura, M. Uehara and K. Togano: Appl. Phys. Lett. 51, 1557 (1987).

2) 北田正弘, 土井俊雄, 梅沢正: 日本金属学会誌 34, 1 (1970).

3) E. Nembach and K. Tachikawa: J. Less-Common Metals 19, 359 (1969).

4) M. K. Wu, J. R. Ashburn, C. J. Torng, P. H. Hor, R. L. Meng, L. Gao, Z. J. Huang, Y. Q. Wang and C. W. Chu: Phys. Rev. Lett. 58 908 (1987).

5) C. P. Bean : Phys. Rev. Lett. 8, 250 (1962).

6) D. Dimos, P. Chaudhari, J. Mannhart and F. K. LeGoues: Phys. Rev. Lett. 61, 219 (1988).

7) 高橋 裕, 森実, 石田洋一: 日本金属学会誌 53, 478 (1989).

8) Y. Hidaka, M. Oda, M. Suzuki, A. Katsui, T. Murakami, N. Kobayashi and Y. Muto: Phisica $148 \mathrm{~B}, 329$ (1987).

9) Y. Hidaka, M. Oda, M. Suzuki, Y. Maeda, Y. Enomoto and T. Murakami : Jpn. J. Appl. Phys 27, L 538 (1988).

10) Y. Takahashi and Y. Ishida : Proc. of MRS Int. Meetings on Advanced Materials, Tokyo 6, 297 (1988).

11) Y. Matsui, H. Maeda, Y. Tanaka, E. Takayama -Muromachi, S. Takekawa and S. Horiuchi: Jpn. J. Appl. Phys. 27, L 827 (1988). 
12) H. W. Zandbergen, W. A. Groen, F. C. Mijlhoff G. van Tendeloo and S. Amelincks: Phisica C 156, 325 (1988).

13) D. A. Smith, M. F. Chisholm and J. Clabes: Appl. Phys. Lett. 53, 2344 (1988).

14) D. L. Kaiser, F. Holtzberg, M. F. Chisholm and T. K. Worthington: J. Cryst. Growth 85, 393 (1987).

15) Y. Takahashi, M. Mori and Y. Ishida: Appl. Phys. Lett. 55, 486 (1989).

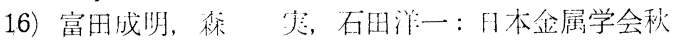

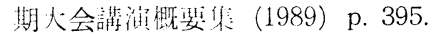

17) Y. Iye, T. Tamegai, T. Sakaki, T. Goto and N. Miura: Phisica C 153-155, 26 (1988).

18）総説として菅原昌敬：材料科学 26, 56 (1989).

19). M. Takano, J. Takeda, K. Oda, H. Kitabuchi, Y. Miura, Y. Ikeda, Y. Tomii and H. Mazaki: Jpn. J. Appl. Phys. 27, L 1041 (1988).

20) T. Komatsu, K. Imai, R. Sato, K. Matsushita and T. Yamashita: Jpn. J. Appl. Phys. 27, L 533 (1988).

21)たとえば P. B. Hirsch, A. Howie, R. B. Nicholson and D. W. Pashley: "Electron Microscopy of Thin Crystals" (Butterworths, London, 1965) p. 388.

22) Y. Ishida, Y. Takahashi, M. Mori and M. Iwatsuki : J pn. J. Appl. Phys. 26, L 690 (1987).

\section{追記}

本原稿を脱稿した後に $\mathrm{Bi}_{2} \mathrm{Sr}_{2} \mathrm{CaCu}_{2} \mathrm{O}_{x}$ 双結品の垁験 に拉いて少し進殿がみられたのでこれを補足してお $\left\langle{ }^{16)}\right.$ 。

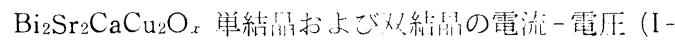

V) 測实に扔いて (図 10)。

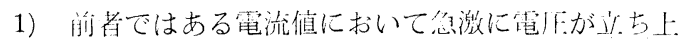
がる。これはバルクの臨界電流值において超伝渓吽

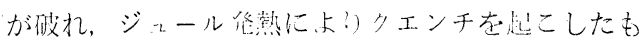
の上宩元以机る。

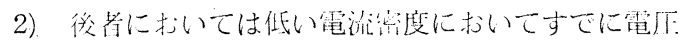

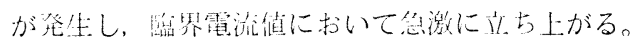

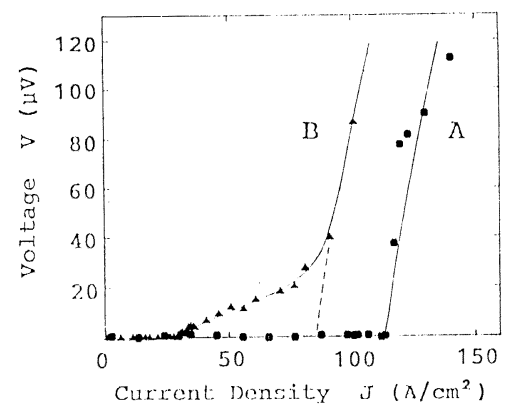

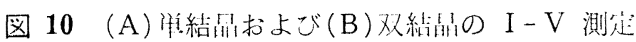
の結渠。(電流密度 $J$ は電流值を断面積で割るこ こにより計算した。)

このため電流一電圧曲線に裾が現われ，粒界の弱結

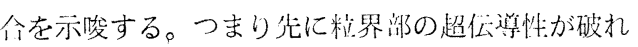
るた如電厅が発生し，その後にバルクが破れたと考 えられる。

このような解秎に其づき形状因子（試料の断面䅡およ

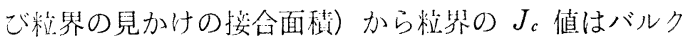
值の $1 / 30$ 程度であることが算出され，[001] ねじり粒 界はやはり弱絬命部である。また双絬间においては大き な電流を流した場合，粒界で発熱を起こしてての部分で 制机てしまうこよが多く, やはり電気的に弱い部分のよ うである。

この得られた值は当初の予想よりはるかに大きい。っ まり,

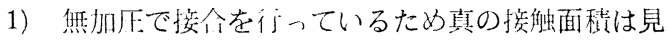
かけより小さい。

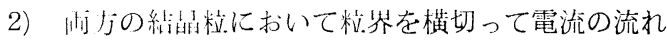

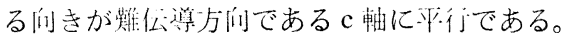
などの理由により，バルク值の 1/1000 以下であると推 測していた。

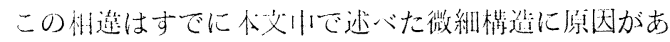

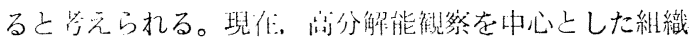
この対匛解明を急いでいる。 